\title{
LOCALIZATION OF ACID PHOSPHATASE ACTIVITY IN THE TESTIS OF TWO TELEOSTEAN SPECIES (Oreochromis niloticus and Odonthestes perugiae)
}

\author{
PORAWSKI, M., ${ }^{1}$ WASSERMANN, G. F. ${ }^{1}$ and ACHAVAL, M. ${ }^{2}$ \\ ${ }^{1}$ Departamento de Fisiologia \\ ${ }^{2}$ Laboratório de Histofisiologia Comparada, Departamento de \\ Ciências Morfológicas, Instituto de Ciências Básicas da Saúde, Universidade Federal do Rio Grande do Sul, \\ CEP 90050-170, Porto Alegre, RS, Brazil \\ Correspondence to: Matilde Achaval, Laboratório de Histofisiologia Comparada, Departamento de Ciências \\ Morfológicas, Instituto de Ciências Básicas da Saúde, UFRGS, Rua Sarmento Leite, 500, CEP 90050-170, \\ Porto Alegre, RS, Brazil \\ Received September 9, 2002 - Accepted January 24, 2003 - Distributed November 30, 2004
}

(With 2 figures)

\begin{abstract}
Acid phosphatase (AcP) activity was investigated in the testes of two species of teleosts in two seasons: summer and winter. AcP activity was detected in Sertoli cells from tilapia (Oreochromis niloticus) only during the nonreproductive period of its annual cycle, corresponding to the winter months. In kingfish (Odonthestes perugiae), the enzymatic reaction was identified during the non-reproductive period (summer) in epithelial cells of the efferent ducts but not in Sertoli cells. These data suggest that the enzyme is involved in the absorption of residual spermatid cytoplasm and as well as in the removal of spermatozoa remaining after the reproductive period. In kingfish, this heterophagous function is carried out by the efferent duct cells and not by Sertoli cells.
\end{abstract}

Key words: testis, seminiferous tubules, Sertoli cells, acid phosphatase, teleosts.

\section{RESUMO}

\section{Localização da atividade da fosfatase ácida em duas espécies de teleósteos (Oreochromis niloticus e Odonthestes perugiae)}

A atividade da fosfatase ácida (AcP) foi estudada em duas espécies de teleósteos em duas estações: verão e inverno. A atividade AcP foi detectada em células de Sertoli de tilápia (Oreochromis niloticus) somente durante o período não reprodutivo de seu ciclo anual, que corresponde aos meses de inverno. Em peixerei (Odonthestes perugiae), a reação enzimática foi detectada durante o período não reprodutivo (verão) nas células epiteliais dos dutos eferentes, porém não foi detectada nas células de Sertoli. Esses dados sugerem que essa enzima está envolvida no processo de reabsorção do citoplasma residual das espermátides e também na remoção dos espermatozóides remanescentes do período reprodutivo. Em peixe-rei, essa função heterofágica é realizada pelas células dos dutos eferentes e não pelas células de Sertoli.

Palavras-chave: testículos, túbulos seminíferos, células de Sertoli, fosfatase ácida, teleósteos.

\section{INTRODUCTION}

One of the functions of Sertoli cells in fish is the phagocytosis of spermatid residual bodies (Grier, 1981; Andrade et al., 2001). This role, essential in the regulation of the seminiferous tubule functioning, depends on lysosome presence. It is well known that acid phosphatase activity (AcP) is present in lysosomes of Sertoli cells, which have a heterophagous function (Van den Hurk et al., 1974; Chemes, 1986). In rats, the digestion of residual bodies is likely to begin with autophagy in spermatids and be completed with phagocytosis of residual bodies by Sertoli cells. This phagocytic function seems to be hormone-independent (Chemes, 1986). 
In teleosts, Sertoli cells surround germinal cells in the same developmental stage, forming germinal cysts (Grier et al., 1978; Silva \& Godinho, 1989; Weltzien et al., 2002). Tilapia (Oreochromis niloticus) belongs to the family Ciclidae, and is bred all over the world. While in tropical climates the fish is able to reproduce all year round, in temperate climates, such as southern Brazil, reproduction is cyclical with two distinct seasons: a reproductive period during spring and summer (October to March) and a nonreproductive period in winter (May to August). Tilapia has an unrestricted type of testis arrangement (Grier et al., 1980), in which spermatogonia appear along the length of tubules (Fig. 1A).

Kingfish (Odonthestes perugiae) is a freshwater fish belonging to the family Atherinidae. It reproduces like tilapia via external fertilization; its reproductive period extends from late winter to spring (from August to October). The seminiferous tubules are organized in a restricted manner. The spermatogonia are located in the distal region of the tubules, and later stages of spermatogenesis are progressively distributed in sequential order from the surface to the center of the testis (Porawski, 1994). In testes organized according to the restricted spermatogonial testis type (Grier et al., 1980), the efferent duct system links the seminiferous tubules to the deferent duct (Fig. 1B). A number of authors agree that these efferent ducts are formed by modified Sertoli cells (Grier et al., 1980; Grier, 1981; Selman \& Wallace, 1986). However, the epithelial cells of the efferent ducts are morphologically very different from Sertoli cells that form germinal cysts (Porawski, 1994; Porawski et al., 1997a).
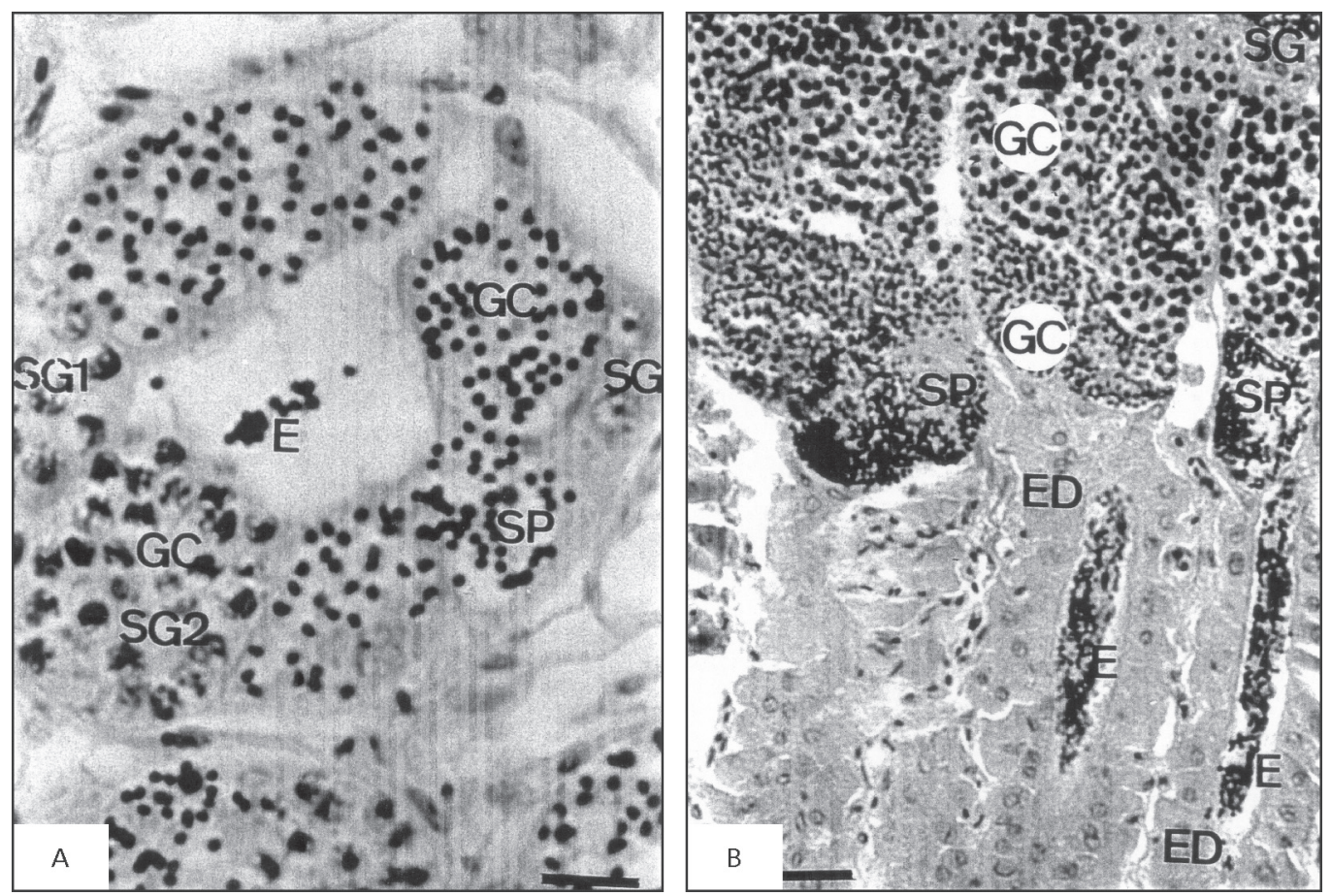

Fig. 1 - A) Photomicrographs of transverse sections of tilapia testis showing a tubule cut transversally. GC - germinal cysts; E - spermatozoa; SG - spermatogonias; SG1 - primary spermatocytes; SG2 - secondary spermatocytes; SP - spermatides. Scale bars: $100 \mu \mathrm{m}$. B) Photomicrographs of transverse sections of kingfish testis showing a tubule cut longitudinally. GC - germinal cysts; ED - efferent duct; E - spermatozoids; SG - spermatogonias; SP - spermatides. Scale bars: $50 \mu \mathrm{m}$. 
The aim of the present work was to determine the localization of AcP activity in the testes of two teleostean fishes (Oreochromis niloticus and Odonthestes perugiae) in order to identify the cell type responsible for the phagocytic function.

\section{MATERIAL AND METHODS}

Adult male specimens of kingfish (Odonthestes perugiae) were captured in the Pinguela Lake, Osório, RS, in winter (June to August) and summer (December to February). Adult male specimens of tilapia (Oreochromis niloticus), were bred and kept in the Aquaculture Laboratory of the Agronomy College, UFRGS, under natural photoperiod and temperature conditions.

The gonads used in this study were found to be in two distinct conditions: a) mature gonads (producing sperm) corresponding to the "reproductive period", identified as the summer months in the case of the tilapia (15) and in the winter months in the case of the kingfish (10); b) inactive gonads (no semen present) corresponding to the "nonreproductive period", identified in the winter months in the case of tilapia (12) and in the summer months in the case of the kingfish (10).

Animals were decapitated and their gonads removed, dissected, and fixed in 4\% paraformaldehyde (REAGEN) diluted in $0.1 \mathrm{M}$ phosphate buffer $\mathrm{pH} 7.4(\mathrm{~PB})$ at $4^{\circ} \mathrm{C}$, for 6 hours. They were then cryoprotected in $15 \%$ and $30 \%$ sucrose (MERCK) solutions in $\mathrm{PB}$ at $4{ }^{\circ} \mathrm{C}$ with continuous agitation until they sank. Sections $(15 \mu \mathrm{m})$ were obtained using a cryostat (Leitz Digital), placed onto gelatinized coverslips, and air dried for 1020 minutes. The sections were incubated at $37^{\circ} \mathrm{C}$ for 2 hours in a medium containing sodium- $\beta$ glycerophosphate (SIGMA), lead nitrate, trismaleate buffer $\mathrm{pH} 5.0$ (TMB). The enzymatic reaction was developed with ammonium sulfide (MERCK), washed again, and covered with a glycerin-jelly solution and slides. Control sections were incubated in a medium without substrate (Gomori, 1952; Pearse, 1972). Then sections were examined and photographed with a Nikon ptiphot-
2 microscope equipped with a Nikon FX-35DX camera.

\section{RESULTS}

Tilapia and kingfish testes displayed AcP activity in specific seasons of the year. Nevertheless, in both species the reaction was differently distributed across the testicular area. The enzymatic reaction appeared as a brownish granular precipitate in the cell cytoplasm. Control sections of both species did not develop any reaction.

In tilapia testis, AcP reaction was only detected in cold months (July and August), corresponding to the non-reproductive period (Fig. 2A). No enzymatic activity was identified in the summer (Fig. 2B), while in winter the reaction was not uniformly distributed in the testis. Intense positive activity occurred in the germinal cysts located closer to the deferent ducts, while the peripheral zone displayed a mild reaction (Fig. 2A). In the germinal cyst, the enzymatic activity was detected in the outermost region which is occupied by Sertoli cells. The cytoplasm of these cells showed uniform distribution of positive granules, which gave a homogeneous aspect to the reaction (Figs. 2C and 2D). Positive reactivity was also detected in the apical zone of deferent duct epithelial cells.

In the kingfish testis, the enzymatic activity was only observed in the nonreproductive period of its seasonal cycle, which goes from spring to summer (Porawski, 1994). When detected, AcP reaction was also not uniformly distributed. No enzymatic reactivity occurred in the seminiferous tubules, where the germinal cysts are located (Fig. $2 \mathrm{E})$. However, an intense enzymatic reaction was found throughout the efferent duct, where the lumen is full of spermatozoa (Figs. 2E and 2F). In the cytoplasm of the simple columnar epithelium lining the efferent ducts, a strong enzymatic reaction appeared which was homogeneously distributed in the apical domain. No reaction was identified in other areas of the cytoplasm (Fig. 2F). However, an intense reaction was observed in the epithelial cells of the deferent duct (DD) (Fig. 2E). 

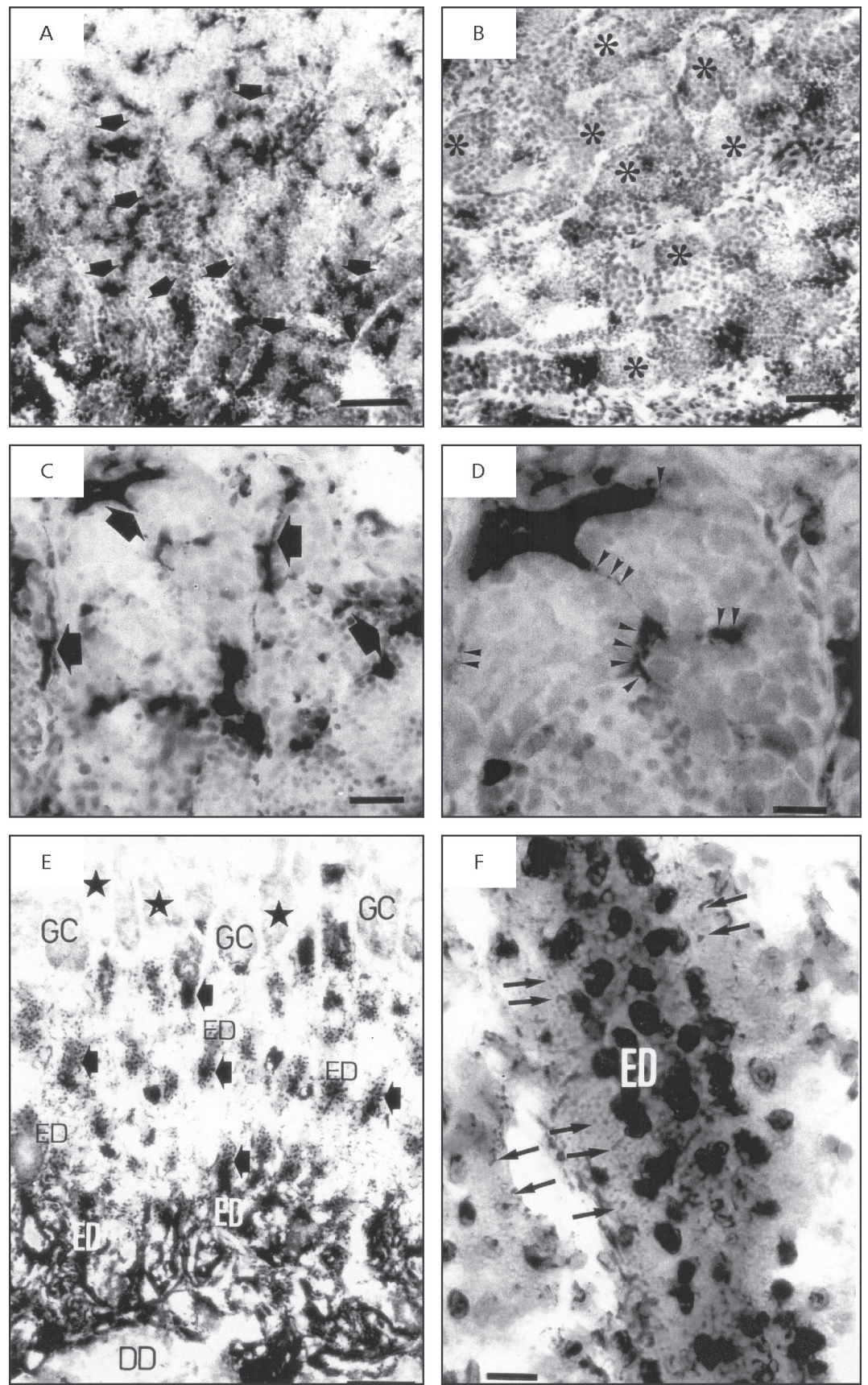

Fig. 2 - A, B, C, and D are photomicrographs of transverse sections of tilapia testis showing the distribution of acid phosphatase activity. A) Gonad in nonreproductive period. Note the strongly positive reaction in the region adjacent to the deferent duct (arrows). B) Gonad in reproductive period, showing negative enzymatic reaction (stars). C) Gonad in nonreproductive period. Note that AcP is located in Sertoli cell that surrounds germ cysts (arrows). D) Detail of previous figure showing cytoplasmatic processes of Sertoli cell with labeled lysosomes (arrowhead). Scale bars: A and B $=100 \mu \mathrm{m} ; \mathrm{C}=50 \mu \mathrm{m} ; \mathrm{D}=20 \mu \mathrm{m}$. E and F are photomicrographs of transverse sections of kingfish testis showing the distribution of acid phosphatase activity in the nonreproductive period. E) Note negative reaction at the germinal cyst level (stars). The apical cytoplasm of the epithelium of efferent and deferent ducts displays a strong enzymatic labeling (arrows). F) Detail of E figure showing labeled lysosomes in the apical cytoplasm of the epithelial cells (arrows). Scale bars: $E=100 \mu \mathrm{m} ; \mathrm{F}=20 \mu \mathrm{m}$. Efferent duct (ED); deferent duct (DD); germinal cysts (GC). 


\section{DISCUSSION}

In tilapia and kingfish testes, positive $\mathrm{AcP}$ activity was observed only in the nonreproductive period. Acid hydrolases in lizard epididymis showed different activity in the reproductive cycle. In Phymaturus palluma, acid hydrolytic activity was intense in the nonreproductive period. However, in another lizard species, Liolemus elongatus, the activity of acid hydrolases was intense in the reproductive period (Grimalt et al., 1995). These authors postulated that the epididymal acid hydrolases may be under hormonal control in the studied lizards. On the other hand, AcP activity is not hormonedependent in rats (Chemes, 1986). But the human testicular acid phosphatase gene was found to be up-regulated by androgens and down-regulated by estrogen (Yousef et al., 2001). In addition, intense $\alpha$-mannosidase activity in the epididymal epithelium of horses occurred in the period of testicular inactivity, which indicates that this enzyme may participate in the removal of spermatozoa remaining after the reproductive period (Álvarez \& Obregón, 1995). Therefore, epididymal acid hydrolases may be under hormonal control during the reproductive period and/ or playing a role in the process of organ remodeling (Grimalt et al., 1995). Therefore, we can suppose that testicular acid phosphatase activity in both fish species may be involved in the removal of spermatozoa remaining after the reproductive period, because this enzymatic activity only appeared in nonreproductive periods.

During the nonreproductive period in tilapia, positive AcP activity appeared in those testicular regions lying close to the deferent duct and within the duct itself. Therefore, AcP-containing lysosomes were found in Sertoli cells of cysts in more advanced stages of spermatogenesis. This finding indicates involvement of these cells in the phagocytic function. Contrarily, in the nonreproductive period of the kingfish, negative AcP activity was observed in Sertoli cells, showing an absence of enzymatic reaction in germinal cysts. However, an intense, uniformly distributed reaction was identified in the efferent duct epithelia. The presence of AcP-containing lysosomes in the efferent duct cells, and not in Sertoli cells of germinal cysts, shows that the absorption of spermatid residual bodies takes place mainly in the efferent ducts, and such cells play an important role in regulating seminiferous tubule functioning. According to some authors, the phagocytic function presented by these cells is typical of Sertoli cells but not of other cell types (Grier et al., 1980; Grier, 1981; Selman \& Wallace, 1986). Nevertheless, AcP-containing lysosomes are similarly found in spermatogonia and late spermatids in rat testis, and a significant increase in AcP activity is observed in the Golgi complex during spermiogenesis (Chemes, 1986). In Bubalus bubalis, a granular distribution of AcP was present in the luminal region of the epithelium of the efferent ductules and in the epididymis (Ariyaratna et al., 1996). In addition, the horse testis presents AcP activity in epididymal cells as well as in isolated cells of the epididymal lumen. Both cells seem to be involved in removal of injured spermatozoa as well as sperm excess remaining after the reproductive period (Álvarez \& Obregón, 1995). Hence, in kingfish, efferent duct cells would act in the same way as horse epididymal cells, presenting or having a spermatophagous function by reabsorbing sperm not employed during the reproductive period, in addition to the function of reabsorbing spermatid residual bodies (Álvarez \& Obregón, 1995).

Therefore, the presence of AcP seems not to be an exclusive characteristic of Sertoli cells. Further studies are needed to determine the nature of the cells that constitute the efferent duct in kingfish testis and their role in seminiferous tubule functioning. The efferent duct system in kingfish seems to play a major role in the spermiogenesis of this species, as it lies in an advantageous anatomical position, between germinal cysts and the deferent duct, i.e., between the sites of production and release of spermatozoa. Furthermore, the region of efferent ducts is characterized by the presence of a great number of lipids (Porawski, 1994), a developed capillary network in the interstitial region adjacent to the ducts (Porawski et al., 1997b), and the presence of AcP activity in the cytoplasm of the cells that constitute these ducts involved in the absorption processes.

Therefore, the efferent duct system in kingfish may play different roles, such as in the absorption of spermatid residual bodies, that may influence the maturation of spermatozoa, as well as its transport and storage, in addition to having an important spermatophagous function following the reproductive period. 
Acknowledgements - This study was supported by grants from Coordenação e Aperfeiçoamento de Pessoal de Nível Superior (CAPES), Conselho Nacional de Desenvolvimento Científico e Tecnológico (CNPq), Fundação de Amparo à Pesquisa do Rio Grande do Sul (FAPERGS), and Convênio UFRGS/FINEP n. 66.91.0509.00.

\section{REFERENCES}

ÁLVAREZ, M. L. L. \& OBREGÓN, E. B., 1995, Spermatophagy in the stallion epididymis: a scanning and transmission electron microscopy study. Acta Anat., 153: 181-188.

ANDRADE, R. F., BAZZOLI, N., RIZZO, E. \& SATO, Y., 2001. Continuous gametogenesis in the neotropical freshwater teleost, Bryconops affinis (Pisces Characidae). Tissue \& Cell, 33: 525-532.

ARIYARATNA, H. B., GUNAWARDANA, V. K. \& NAVARATNE, M. A., 1996, The epididymis of prepubertal swamp buffalo (Bubalus bubalis): histochemistry of phosphatases. Anatomia, Histologia, Embryologia, 25(3): 161-165.

CHEMES, H., 1986, The phagocitic function of Sertoli cells: a morphological, biochemical and endocrinological study of lysosomes and acid phosphatase localization in the rat testis. Endocrinology, 119: 1673-1681.

GOMORI, T., 1952, Microscopic histochemistry: principles and practices. University of Chicago Press, Chicago, p. 193.

GRIER, H. J., FITZSIMONS, J. M. \& LINTON, J. R., 1978, Structure and ultrastructure of the testis and sperm formation in Goodeid teleost. J. Morph., 156: 419-438.

GRIER, H. J., LINTON, J. R., LEATHERLAND, J. F. \& DE VLAMING, V. L., 1980, Structural evidence for two different testicular types in teleost fishes. Amer. J. Anat., 159: 331345 .

GRIER, H. J., 1981, Cellular organization of the testis and spermatogenesis in fishes. Amer. Zool., 21: 345-357.
GRIMALT, P. E., CASTRO, L. P., MAYORGA, L. S. \& BERTINI, F., 1995, Epididymal acid hydrolases in the annual reproductive cycle of two lizards. Comp. Biochem. Physiol., 112A: 321-325.

PEARSE, A. G. E., 1972, Histochemistry, theoretical and applied, vol. 2, 3. ed. Edinburgh, Churchill Livingstone.

PORAWSKI, M., 1994, Determinação do estágio de maturação gonadal em peixe- rei, gênero Odonthestes. Dissertação de Mestrado, Curso de Pós-graduação em Ciências Biológicas: Fisiologia, UFRGS, Porto Alegre, RS, Brasil.

PORAWSKI, M., WASSERMANN, G. F. \& ACHAVAL, M., 1997a, Functional morphology of male gonad of kingfish. Rev. Bras. Biol., 57: 151-159.

PORAWSKI, M., LIMA, K., WASSERMANN, G. F. \& ACHAVAL, M., 1997b, Locazation of alkaline phosphatase activity in teleostean testis. Braz. J. Morphol. Sci., 14: 103.

SELMAN, K. \& WALLACE, A. R., 1986, Gametogenesis in Fundulus heteroclitus. Amer. Zool., 26: 173-192.

SILVA, M. \& GODINHO, H., 1989, A célula de Sertoli de Oreochromis niloticus (Peixe, teleósteo). Rev. Bras. Ciên. Morf., 6: 3-8.

VAN DEN HURK, R., MEEK, J. \& PEUTE, J., 1974, Ultrastructural study of the testis of the black molly (Mollienisia Latipinna) I. The intratesticular efferent duct system. Endocrinology, 77: 5.

WELTZIEN, F. A., TARANGER, G. L., KARLSEN, O. \& NORBERG, B., 2002, Spermatogenesis and related plasma androgen levels in Atlantic halibut (Hyppoglossus hyppoglossus L.). Comp. Biochem. Physiol., 1132A: $567-$ 575.

YOUSEF, G. M., DIAMANDIS, M., JUNG, K. \& DIAMANDIS, E. P., 2001, Molecular cloning of a novel human acid phosphatase gene (ACPT) that is highly expressed in the testis. Genomics, 74: 385-395. 